\title{
PENGARUH PENERAPAN DISIPLIN PREVENTIF DAN DISIPLIN KOREKTIF TERHADAP PRESTASI KERJA TENAGA KEPENDIDIKAN
}

\author{
Cecep $^{1}$ \\ Rahman Tanjung ${ }^{2}$ \\ Tatang Taryana ${ }^{3}$ \\ Devi Sulaeman ${ }^{4}$ \\ Nasem $^{5}$ \\ ${ }^{1}$ PGMI, STIT Rakeyan Santang Karawang \\ Email : cecepsundulusi2@gmail.com \\ ${ }^{2}$ PGMI, STIT Rakeyan Santang Karawang \\ Email : rahmantanjung1981@gmail.com \\ ${ }^{3}$ PGMI, STIT Rakeyan Santang Karawang \\ Email : tatangtaryana151@gmail.com \\ ${ }^{4}$ PGMI, STIT Rakeyan Santang Karawang \\ Email devisulaeman @gmail.com \\ ${ }^{5}$ PGMI, STIT Rakeyan Santang Karawang \\ Email : adenasem2204@gmail.com
}

\begin{abstract}
ABSTRAK
Disiplin kerja pegawai tercermin dari besarnya rasa tanggung jawab pegawai dalam menyelesaikan tugas tepat waktu, tingkat keterlambatan pegawai yang rendah karena adanya semangat dan gairah kerja dan meningkatnya efisiensi dan produktivitas pegawai yang ditunjukan dengan tingkat ketidakhadiran pegawai yang rendah. Penelitian ini dilakukan ingin mengetahui pengaruh secara simultan disiplin perventif dan displin korektif terhadap prestasi kerja tenaga kependidikan dan pengaruh secara parsial disiplin perventif dan displin korektif terhadap prestasi kerja tenaga kependidikan STIT Rakeyan Santang Karawang. Dari table anova diperoleh nilai $F$ hitung sebesar 600,888 > F tabel 3.23 dan nilai probabilitas $($ Sig $)=0.000$ lebih kecil dari nilai probabilitas 0.05 atau nilai $0.000<0.05$ berarti H1 diterima, berarti secara bersama-sama (simultan) variabel (X1) Disiplin Preventif dan (X2) Disiplin Korektif berpengaruh secara signifikan terhadap variabel (Y) Prestasi Kerja. $t$ hitung (2.353) $>$ t tabel 1.6829, dan Sig 0.023 lebih kecil dari nilai probabilitas 0.05 atau nilai $0.023<0.05$ berarti Ho ditolak. koefisien X2 berpengaruh secara signifikan terhadap variabel, (Y) Prestasi Kerja $t$ hitung (22.911) > t tabel 1.6829, dan Sig 0.000 lebih kecil dari nilai probabilitas 0.05 atau nilai $0.000<0.05$ berarti Ho ditolak. koefisien X1 berpengaruh secara signifikan terhadap variabel, (Y) Prestasi Kerja.
\end{abstract}

Kata Kunci : Disiplin, Preventif, Korektif

\section{PENDAHULUAN}

Saat ini tampak suatu fenomena administratif pada organisasi. Begitu pun terjadi pada STIT Rakeyan Santang Karawang yang ditandai dengan semakin besarnya perhatian terhadap pentingnya manajemen sumberdaya manusia, yaitu membantu mengelola orang dalam suatu organisasi yang menekankan pada pembentukan, pemeliharaan dan pengembangan sistem yang menyediakan kerangka kerja bagi pegawai. Calon pegawai melewati seleksi berdasarkan kualifikasi kompetensi yang dimiliki oleh masing-masing individu agar dalam pelaksanaan kerja nantinya pegawai dapat bekerja dengan baik dan memiliki prestasi kerja yang memuaskan. Pengelolaan sumberdaya manusia yang baik diperlukan untuk meningkatkan potensi pengetahuan dan wawasan, keterampilan kerja, kemampuan manajerial, sikap dan kepribadian, kedisiplinan dan prestasi kerja. Menurut (Arifudin, 2020) perkembangan dalam dunia usaha di Indonesia saat ini yang semakin cepat dan pesat berakibat juga pada perubahan budaya. Sehingga organisasi dituntut untuk mempunyai budaya yang membedakan dengan organisasi lain yang sejenis. Langkah awal untuk mencapai prestasi kerja yang diharapkan harus dimulai dari disiplin. Seorang 
pegawai dikatakan disiplin jika memenuhi tiga faktor yaitu, menaati waktu kerja, melakukan pekerjaan dengan baik, serta mematuhi semua peraturan dan norma sosial.

Secara garis besar visi STIT Rakeyan Santang berisi sumber daya yang memiliki potensi untuk mewujudkan perguruan tinggi yang tanggap terhadap setiap perubahan, serta sanggup menyesuaikan diri terhadap perubahan-perubahan yang terjadi, tidak mudah menyerah, bekerja keras menyongsong masa depan yang lebih baik, dilandasi dengan kebaikan hati dan rasa keimanan kepada Allah SWT. Serta dilandasi oleh kebutuhan pada pendidikan yang lebih baik untuk meningkatkan kualitas hidup dan mampu mengimbangi arus perubahan pada setiap sektor yang kini semakin maju, kebutuhan pada kedamaian dan ketentraman hati yang dihiasi dengan akhlak mulia masyarakat sehingga tercapai kehidupan yang nyaman, tentram disertai dengan iman dan taqwa. Hal ini menjadi motivasi dalam melakukan penelitian terkait penerapan disiplin kerja terhadap prestasi kerja tenaga kependidikan STIT Rakeyan Santang Karawang.

Disiplin kerja pegawai merupakan referensi dari sebuah kinerja pegawai terhadap tugas dan tanggung jawabnya. Menurut (Rokhmawati, 2013) kinerja merupakan catatan terhadap hasil produksi dan pekerjaan atau aktivitas tertentu dalam periode waktu tertentu. Kinerja yang berlangsung hingga pensiun menjadi karier seseorang. Tanggung jawab pencapaian karier dan peningkatan prestasi kerja sebenarnya merupakan tanggung jawab individu, namun hal tersebut menjadi bijaksana ketika perusahaan memberi gambaran dan arahan melalui penilaian prestasi kerja.

Menurut (Jackson, 2010) menetapkan standart utama dalam mengukur kinerja karyawan, yaitu sebagai berikut : 1) Quantity of output (kuantitas keluaran) yakni Standar keluaran (output) lebih banyak digunakan untuk menilai prestasi karyawan di bagian produksi atau teknis, 2) Quality of output (kualitas keluaran) yakni Jika yang digunakan dalam mengukur prestasi kerja karyawan itu, 3) Timelines of output (waktu keluaran) yakni Ketepatan waktu yang digunakan dalam menghasilkan sebuah barang sering digunakan sebagai ukuran atau penilaian terhadap prestasi kerja, 4) Presences at work (tingkat kehadiran) yakni Jika kehadiran karyawan di bawah standar hari kerja yang ditetapkan maka karyawan tersebut tidak akan mampu memberikan kontribusi yang optimal terhadap organisasi, 5) Efficiency of work completed (efisiensi pekerjaan yang telah diselesaikan) yakni Melakukan setiap kegiatan suatu organisasi dengan tujuan untuk dapat memperoleh hasil yang dikehendaki dengan usaha yang seminimal mungkin sesuai dengan standar yang ada, dan 6) Effectiveness of work completed (efektivitas pekerjaan yang telah diselesaikan) yakni suatu pekerjaan dikatakan efektif jika diselesaikan tepat pada waktunya sesuai dengan rencana.

Berdasarkan data-data yang ada terkait prestasi kerja tenaga kependidikan STIT Rakeyan Santang menunjukkan adanya peningkatan. Sehingga penulis tertarik untuk melakukan penelitian secara komprehensif terkait Pengaruh Penerapan Disiplin Kerja Terhadap Prestasi Kerja tenaga kependidikan STIT Rakeyan Santang Karawang. Tujuan penelitian ini diharapkan dapat menjadi masukan terhadap peningkatan kinerja tenaga kependidikan STIT Rakeyan Santang Karawang, sebagai upaya melahirkan pelayanan yang semakin baik di masa mendatang.

\section{KAJIAN PUSTAKA}

Menurut (Hasibuan, 2016) berpendapat bahwa disiplin adalah kesadaran dan kesediaan seseorang menaati semua peraturan perusahaan dan norma-norma sosial yang berlaku. Disiplin harus ditegakkan dalam suatu organisasi perusahaan. Tanpa dukungan disiplin karyawan yang baik, sulit perusahaan untuk mewujudkan tujuannya. Jadi, disiplin adalah kunci keberhasilan suatu perusahaan dalam mencapai tujuannya. Sedangkan Menurut (Fahmi, 2016) bahwa disiplin yaitu tingkat kepatuhan dan ketaatan kepada aturan yang berlaku serta bersedia menerima sanksi atau hukuman jika melanggar aturan yang ditetapkan dalam disiplin tersebut. Disiplin menunjukkan suatu kondisi atau sikap hormat yang ada pada diri karyawan terhadap peraturan dan ketetapan perusahaan. Dengan demikian bila peraturan dan ketetapan yang ada dalam perusahaan itu diabaikan, atau sering dilanggar, maka pegawai mempunyai disiplin kerja yang buruk. Sebaliknya, bila pegawai tunduk pada ketetapan perusahaan, menggambarkan adanya kondisi disiplin yang baik. 
Berdasarkan pendapat diatas bahwa dapat diberikan kesimpulan bahwa disiplin merupakan suatu kewajiban yang harus disadari oleh pegawai sebagai wujud peraturan yang harus ditaati dan kesediaan untuk menerima sanksi apabila melanggar ketentuan maupun peraturan yang telah ditetapkan. Adapun pendekatan disiplin yang dilakukan dalam penelitian ini yakni disiplin preventif dan disiplin korektif.

\section{Disiplin Preventif}

Disiplin Preventif merupakan salah satu aspek yang mempengaruhi kinerja pegawai yaitu kedisiplinan. Bahwa tidak dapat dipungkiri kedisiplinan sering menimbulkan permasalahan tersendiri bagi semua organisasi umumnya. Sebuah perusahaan harus membuat pencegahan-pencegahan agar para karyawan tersebut tidak melanggar peraturan-peraturan perusahaan dan untuk mendorong para karyawan di sebuah perusahaan dapat terdorong untuk tidak melanggar aturan yang dilakukan dengan jenis disiplin lain yaitu disiplin preventif. Kompensasi merupakan salah jenis pendorang untuk karyawan disiplin. Menurut (Arifudin, 2019) kompensasi inilah yang akan dipergunakan karyawan itu untuk memenuhi kebutuhan hidupnya.

Menurut (Handoko, 2014) disiplin preventif adalah kegiatan yang dilaksanakan untuk mendorong para karyawannya agar mengikuti berbagai standar dan aturan, sehingga penyelewengan-penyelewengan dapat dicegah. Sejalan dengan pendapat di atas bahwa menurut (Mangkunegara, 2014) disiplin preventif yaitu dimana disiplin yang berupaya menggerakkan pegawainya untuk mengikuti dan mematuhi pedoman kerja, aturan-aturan berlaku yang telah digariskan oleh perusahaan. Sedangkan indikator Disiplin Preventif sangatlah penting dalam upaya agar karyawan dapat mematuhi aturan-aturan yang berlaku di perusahaan. Menurut (Simamora, 2014) menyebutkan beberapa indikator disiplin preventif meliputi Kepatuhan pada peraturan, Menyelesaikan pekerjaan tepat waktu, Efektifitas dalam bekerja dan Kehadiran tepat waktu.

\section{Disiplin Korektif}

Menurut (Mangkunegara, 2014) disiplin korektif merupakan suatu upaya untuk menggerakan pegawai dalam suatu peraturan dan mengarahkan untuk tetap mematuhi peraturan sesuai dengan pedoman yang berlaku pada perusahaan. Sedangkan menurut (Handoko, 2014) Disiplin korektif adalah kegiatan yang diambil untuk menangani pelanggaran terhadap aturan-aturab dan mencoba untuk menghindari pelanggaran-pelanggaran lebih lanjut.

\section{METODE PENELITIAN Pendekatan Penelitian}

Penelitian ini menerapkan metode penelitian kuantitatif. Adapun yang melatarbelakangi peneliti memilih metode penelitian kuantitatif karena sudah sesuai dengan tujuan penelitian yang ingin mengetahui Pengaruh Penerapan Disiplin Kerja Terhadap Prestasi Kerja tenaga kependidikan STIT Rakeyan Santang Karawang. Penelitian ini tergolong jenis penelitian kausal karena ingin mencari bagaimana dampak dari penerepan disiplin yang dilakukan oleh pegawai dan dampak dari penerapan disiplin pada prestasi kerja pegawai.

\section{Metode Pengumpulan Data}

Data yang digunakan dalam penelitian ini berupa data primer dan data sekunder. Data primer diperoleh dengan melakukan pengamatan langsung di lapangan, wawancara dengan pihak-pihak yang terkait yaitu Pimpinan perguruan tinggi dan jajarannya, serta melalui hasil pengisian kuesioner mengenai disiplin preventif, disiplin korektif dan prestasi kerja yang diberikan kepada tenaga kependidikan STIT Rakeyan Santang Karawang sebagai responden. Adapun responden yakni memiliki latar belakang pendidikan S1. Sedangkan data sekunder diperoleh dari hasil studi kepustakaan, arsip data dan berbagai literatur, baik berupa buku yang memuat teori-teori, hasil penelitian terdahulu, serta pencatatan data-data yang sudah ada.

Persiapan penelitian yang dilakukan adalah dengan melakukan studi kepustakaan diperoleh dan dikumpulkan dengan cara membaca, mempelajari, dan mengutip pendapat dari berbagai sumber buku, laporan atau dokumen dan sumber lainnya yang berkaitan dengan permasalahan yang diteliti. Sedangkan 
terkait data-data yang diperoleh dari lapangan yakni dengan menyiapkan pertanyaan penelitian yang sesuai dengan permasalahan yang diteliti.

\section{Analisis Data}

Uji Validitas

Uji validitas digunakan untuk menunjukan sejauh mana alat ukur mengukur apa yang ingin diukur atau apakah alat ukur tersebut sudah tepat mengukur apa yang akan diukur. Asumsi pokok dari uji validitas ini adalah setiap pertanyaan saling berkaitan antara satu dengan yang lainnya dan menghubungkan dengan objek yang diteliti. Uji validitas menunjukkan sejauh mana alat pengukur itu mengukur hal yang akan diukur. Langkah-langkah dalam melakukan uji validitas kuesioner adalah sebagai berikut :

a. Mendefinisikan secara operasional konsep yang akan diukur, yaitu dengan cara:

1) Mencari definisi dan rumusan konsep dan literatur, jika sekiranya sudah ada rumusan yang cukup rasional, maka rumusan tersebut dapat langsung dipakai. Tetapi bila rumusan tersebut belum operasional, maka peneliti harus merumuskannya seoperasional mungkin.

2) Jika dalam literatur tidak diperoleh definisi atau rumusan konsep yang akan diukur, peneliti harus mendiskusikan dengan para ahli lain. Pendapat para ahli ini kemudian disarikan ke dalam bentuk rumusan yang operasional.

3) Menanyakan langsung kepada calon responden penelitian mengenai aspek-aspek konsep yang menyusun pertanyaan yang operasional.

b. Melakukan uji coba skala pengukuran pada sejumlah responden. Jumlah responden untuk uji coba minimal adalah 30 orang, karena distribusi skor atau nilai akan lebih mendekati normal. Asumsi kurva normal sangat dibutuhkan dalam perhitungan statistik.

c. Mempersiapkan tabel tabulasi jawaban.

d. Menghitung antara masing-masing pertanyaan atau pertanyaan dengan skor total dan menggunakan rumus Product Moment, yaitu:

$$
\begin{aligned}
& \text { Keterangan : rxy }=\text { koir } r y y=\frac{N \sum x y-\left(\sum x\right)\left(\sum y\right)}{\sqrt{N \sum X^{2}-\left(\sum x\right)^{2}\left|N \sum Y^{2}-\left(\sum Y\right)^{2}\right|}} \\
& \begin{array}{l}
\mathrm{X}=\text { jumlah responden } \\
\mathrm{Y}=\text { skor masing-masing pertanyaan }
\end{array}
\end{aligned}
$$

\section{Uji Reliabilitas}

Reliabilitas adalah indeks yang menunjukkan sejauh mana alat pengukur dapat dipercaya atau diandalkan. Pengujian reliabilitas yang digunakan yaitu teknik Cronbach. Teknik Cronbach digunakan untuk mencari reliabilitas dengan instrumen yang skornya rentangan antara beberapa nilai, misalnya 0-10 atau 0-1000 atau bentuk skala 1-3, 1-5 atau 1-7 dan seterusnya. George dan Mallery (2003), menyatakan bahwa koefisien Alpha Cronbach berada diantara 0 dan 1. Semakin mendekati angka 1,0 maka semakin baik kekonsistenan instrumen yang diuji.

Analisis Linier Berganda

Analisis regresi berganda digunakan dalam penelitian ini karena peubah bebas yang digunakan lebih dari satu. Analisis regresi berganda merupakan analisis yang bertujuan mencari besarnya pengaruh peubah bebas (dependen) terhadap peubah respon (independen) atau berkenaan dengan studi ketergantungan satu peubah (peubah respon) pada satu atau beberapa peubah lain (peubah bebas). Peubah bebas (independen) yang dimaksud adalah disiplin preventif dan disiplin korektif. Sedangkan perubah dependen yang dimaksud adalah prestasi tenaga kependidikan STIT Rakeyan Santang Karawang. 
Rumus yang digunakan dalam analisis regresi linier sederhana ini adalah seperti yang dikemukakan oleh Umar (2004) :

$\mathrm{Y}=\mathrm{a}+\mathrm{b} 1 \mathrm{X} 1+\mathrm{b} 2 \mathrm{X} 2+\ldots+\mathrm{bnXk}$

Keterangan :

$\mathrm{Y}=$ peubah terikat (prestasi kerja)

$\mathrm{a}=$ konstanta

$\mathrm{b} 1, \mathrm{~b} 2=$ koefisien arah garis regresi

$\mathrm{X} 1=$ peubah bebas disiplin preventif

$\mathrm{X} 2$ = peubah bebas disiplin korektif

Data yang diperoleh diolah dan dianalisis disesuaikan dengan tujuan yang telah ditentukan. Data dari kuesioner diolah untuk menganalisis pengaruh disiplin kerja terhadap prestasi kerja pegawai adalah :

a. Memberi skor pada masing-masing jawaban responden berdasarkan bobot tertentu pada setiap jawaban dengan menggunakan skala Likert.

b. Memindahkan data dari lembaran kuesioner ke lembar tabulasi danmenghitung nilai total dari masing-masing variabel dengan program SPSS.

Jawaban yang telah diberikan bobot, kemudian dijumlahkan untuk setiap responden guna dijadikan skor penilaian terhadap variabelvariabel yang diteliti. Adapun skor diperoleh dari hasil perkalian antara bobot (skala Likert) dengan persentase jawaban responden.

Uji Asumsi

Multikolinearitas

Uji ini dilakukan untuk menguji apakah pada model regresi ditemukan adanya korelasi antar peubah bebas. Jika terjadi korelasi, maka terdapat problem multikolinearitas. Model regresi yang baik seharusnya tidak terjadi korelasi di antara peubah bebas. Cara untuk melihat model regresi yang bebas multikolinearitas adalah sebagai berikut :

1) Nilai VIF (Variance Inflation Factor) di sekitar angka 1.

2) Nilai Tolerance mendekati 1.

Heteroskedastisitas

Uji ini digunakan untuk menguji apakah di dalam sebuah model regresi terjadi ketidaksamaan ragam residual dari satu pengamatan ke pengamatan yang lain. Jika ragam residual dari satu pengamatan ke pengamatan yang lain tetap, maka disebut homokedastisitas. Dasar pengambilan keputusan untuk mendeteksi adanya Heteroskedastisitas adalah sebagai berikut :

1) Jika ada pola tertentu, seperti titik-titik (points) yang ada membentuk suatu pola tertentu yang teratur (bergeloombang, melebar kemudian menyempit), maka telah terjadi heteroskedastisitas.

2) Jika tidak ada polayang jelas, serta titik-titik menyebar di atasdan di bawah angka 0 pada sumbu Y, maka tidak terjadi heteroskedastisitas.

Autokorelasi

Digunakan untuk menguji apakah dalam sebuah model regresi linier ada korelasi antara kesalahan pengganggu pada periode t-1 (sebelumnya). Jika terjadi korelasi, maka ada problem autokorelasi. Model regresi yang baik adalah model regresi yang bebas dari autokorelasi (Santoso, 2004). Patokan untuk mendeteksi adanya autokorelasi adalah dengan melihat besaran D-W (Durbin-Watson). Angka D-W dapat diambil sebagai berikut :

1) Angka $D-W$ di bawah -2 berarti ada autokorelasi positif.

2) Angka $D-W$ di antara -2 sampai +2 berarti tidak ada autokorelasi.

3) Angka D-W di atas +2 berarti ada autokorelasi negatif. 
Uji t

Uji t digunakan untuk menguji konstanta dari peubah bebas. Hal ini berarti bahwa uji t dapat mengetahui apakah peubah bebas secara individu.

\section{HASIL DAN PEMBAHASAN}

Berdasarkan hasil perhitungan terhadap disiplin preventif, ternyata pelaksanaan disiplin preventif di STIT Rakeyan Santang Karawang sudah baik hal ini dapat dilihat dari hasil pengisian kuesioner oleh 54 orang pegawai sebagai responden. Jumlah pegawai yang selalu mengetahui waktu kerja sebanyak 96,3\% atau sebanyak 52 orang pegawai, pegawai yang selalu melaksanakan pekerjaan dengan baik meskipun pimpinan tidak berada di tempat sebesar $74,1 \%$ atau 40 orang pegawai, pegawai yang selalu memberikan keterangan jika berhalangan hadir sebesar $75,93 \%$ atau 41 orang pegawai, pegawai yang selalu tidak membuang-buang waktu kerja sebanyak 30 orang atau sekitar 55,55\%pegawai, pegawai yang sering menyelesaikan tugas tepat waktu sebanyak 28 orang atau $51,9 \%$, pegawai yang selalu melakukan pekerjaan sesuai dengan prosedur yang telah ditetapkan sebesar 50\% atau 27 orang, pegawai yang hasil kerjanya sering memenuhi tuntutan yang diharapkan sebesar 55,55\% atau sebanyak 30 orang pegawai, pegawai yang selalu berusaha dengan serius dalam menyelesaikan pekerjaan sebanyak 26 orang atau $48,15 \%$, pegawai yang selalu mengetahui dan mematuhi peraturan sebanyak 43 orang atau sebesar $79,63 \%$, pegawai yang mengatakan bahwa pimpinan selalu memberi tahu mengenai prosedur dan peraturan sebesar $51,86 \%$ atau 28 orang, pegawai yang menyatakan bahwa pimpinan selalu memberikan contoh yang baik sebanyak 30 orang atau $55,55 \%$ dan pegawai yang menyatakan bahwa pimpinan dalam menjalankan tugas selalu bertindak adil sebanyak 29 orang atau $53,7 \%$.

Berdasarkan hasil perhitungan terhadap disiplin korektif, ternyata pelaksanaan disiplin korektif di STIT Rakeyan Santang Karawang sudah baik hal ini dapat dilihat dari hasil pengisian kuesioner oleh 54 orang pegawai sebagai responden. Jumlah pegawai yang pernah tidak masuk kerja selama lebih dari tiga hari dalam jangka waktu satu bulan sebanyak 25 orang atau 46,3\%, pegawai yang mengatakan bahwa kadang-kadang diberikan toleransi keterlambatan masuk kerja oleh pimpinan sebanyak 20 orang atau $37,04 \%$, pegawai yang selalu berada di lingkungan kerja pada waktu jam kerja sebesar $74,1 \%$ atau 40 orang, pegawai yang selalu menggunakan waktu istirahat dengan tepat sebanyak 32 orang atau 59,26\%, pegawai yang selalu bertanggung jawab terhadap pekerjaan sebanyak 29 orang atau 53,7\%, pegawai yang pernah terlambat menyelesaikan dan melakukan kesalahan pada waktu penyelesaian tugas sebesar $51,85 \%$ atau 28 orang, pegawai yang terlambat menyelesaikan dan melakukan kesalahan dalam tugas kadang-kadang diberikan sanksi sebanyak 17 orang atau $31,48 \%$, pegawai yang selalu berusaha memperbaiki kesalahan pada tugas yang telah dibebankan sebesar 40,7\% atau 22 orang, pegawai yang selalu siap menerima sanksi jika melanggar peraturan yang telah ditetapkan sebesar 55,55\% atau 30 orang, pegawai yang menyatakan bahwa jika ada yang melanggar peraturan maka akan diberikan sanksi sesuai dengan jenis pelanggaran yang dilakukan sebanyak 30 orang atau 55,55\%, pegawai yang pernah datang terlambat dan pernah mendapatkan teguran dari atasan sebanyak 22 orang atau $40,7 \%$ dan pegawai yang selalu memiliki tekad untuk tidak melanggar peraturan kembali sebanyak 34 orang atau 62,96\%.

Berdasarkan hasil perhitungan terhadap prestasi kerja ternyata pegawai yang selalu melaksanakan pekerjaan sesuai dengan wewenang dan tanggung jawab yang dibebankan sebanyak 28 orang atau $51,86 \%$, pegawai yang selalu merasa nyaman dan termotivasi dalam melakukan tugas yang dibebankan sebanyak 32 orang atau 59,26\%, pegawai yang menyatakan bahwa pekerjaan yang dibebankan selalu sesuai dengan tingkat kemampuan yang dimiliki sebanyak 31orang atau 57,4\%, pegawai yang selalu memiliki kesetiaan terhadap pekerjaan sebesar $74,1 \%$ atau 40 orang, pegawai yang kadang-kadang bertanggung jawab terhadap pekerjaan sebesar $27,78 \%$ atau 15 orang, pegawai yang selalu taat prosedur dalam melaksanakan tugas sebanyak 38 orang atau $35,2 \%$, pegawai yang selalu selalu jujur dalam bekerja sebesar 57,4\% atau 31 orang, pegawai yang selalu bekerjasama dengan pegawai lain dalam pelaksanaan tugas sebanyak 31 orang atau $57,4 \%$, pegawai yang selalu memiliki inisiatif terhadap tugas yang diberikan sebanyak 33 orang atau $61,11 \%$ dan pegawai yang selalu memiliki semangat dan jiwa kepemimpinan yang tinggi sebanyak 32 orang atau 59,26\%. 
Berdasarkan hasil analisis regresi berganda yang terdapat pada tabel di atas maka model regresi yang terbentuk adalah sebagai berikut :

$\mathrm{Y}=-12,689+0,603 \mathrm{X} 1+0,508 \mathrm{X} 2$

Besaran koefisien regresi yang dimiliki oleh peubah independen dapat digunakan perbandingan signifikasi t terhadap alpha yang ditetapkan. Peubah X1 dan X2 dinyatakan memiliki pengaruh terhadap Y apabila signifikasi t hitung $<0,05$. Dari hasil olah data yang diperoleh, maka model regresi tersebut di atas dapat diinterpretasikan sebagai berikut :

1. Tanda positif (+) dan negatif (-) pada model regresi menujukkan arah peningkatan atau penurunan peubah Y (prestasi kerja) yang dipengaruhi oleh peubah X1 (disiplin preventif) dan $\mathrm{X} 2$ (disiplin korektif).

2. Nilai $\mathrm{Y}=-12,689$ saat $\mathrm{X} 1$ dan $\mathrm{X} 2$ bernilai 0 . Hal ini berarti bahwa nilai prestasi ( $\mathrm{Y}$ ) akan menurun sebesar 12,689 saat penerapan disiplin preventif (X1) dan disiplin korektif (X2) tidak dilaksanakan (saat penerapan disiplin bernilai 0).

3. Peubah X1 yaitu disiplin preventif memiliki t hitung sebesar 7,707 dengan tingkat signifikasi sebesar 0,000. Signifikasi $\mathrm{t}<0,05$ maka disiplin preventif memiliki pengaruh yang signifikan terhadap prestasi kerja. Koefisien arah regresi (beta) X1 (penerapan disiplin preventif) sebesar 0,603 dan memiliki arah yang positif terhadap Y (prestasi kerja). Hal ini berarti apabila terjadi peningkatan penerapan disiplin preventif sebesar satu satuan maka akan terjadi peningkatan prestasi kerja pegawai sebesar koefisien arah regresi $(0,603)$.

4. Peubah X2 yaitu disiplin korektif memiliki t hitung sebesar 6,194 dengan tingkat signifikasi sebesar 0,000. Signifikasi $t<0,05$ maka disiplin korektif memiliki pengaruh yang signifikan terhadap prestasi kerja.

Koefisien arah regresi (beta) X2 (penerapan disiplin korektif) sebesar 0,508 dan memiliki arah yang positif terhadap Y (prestasi kerja). Hal ini berarti apabila terjadi peningkatan penerapan disiplin preventif sebesar satu satuan maka akan terjadi peningkatan prestasi kerja pegawai sebesar koefisien arah regresi $(0,508)$.

\section{SIMPULAN DAN SARAN}

\section{Simpulan}

1. Hasil identifikasi penerapan disiplin kerja berupa disiplin preventif dan disiplin korektif pada STIT Rakeyan Santang Karawang, disiplin preventif memiliki pengaruh yang signifikan terhadap prestasi kerja. Hal ini berarti apabila terjadi peningkatan penerapan disiplin preventif maka akan terjadi peningkatan prestasi kerja pegawai.

2. Disiplin korektif memiliki pengaruh yang signifikan terhadap prestasi kerja. Hal ini berarti apabila terjadi peningkatan penerapan disiplin preventif sebesar satu satuan maka akan terjadi peningkatan prestasi kerja pegawai.

3. Hasil uji $\mathrm{F}$ menunjukan disiplin kerja memiliki pengaruh terhadap prestasi kerja dan memiliki pengaruh yang signifikasi. Sehingga dapat dinyatakan bahwa disiplin preventif memiliki pengaruh dominan terhadap prestasi kerja.

\section{Saran}

Beberapa saran yang penulis bisa sampaikan berdasarkan hasil penelitian kepada pihak-pihak terkait, antara lain:

1. Pimpinan intansi dalam hal ini camat disarankan untuk terus mengawasi dan mengendalikan perilaku disiplin ini sehingga menjadi budaya dalam organisasi.

2. Pimpinan intansi dalam hal ini camat harus memberikan reward terkait prestasi kerja pegawai sebagai stimulus pegawai mencapai prestasi kerja. 


\section{DAFTAR PUSTAKA}

Arifudin, O. (2019). Pengaruh Kompensasi Terhadap Kinerja Karyawan Di PT Global (PT.GM). Jurnal Ilmiah MEA (Manajemen, Ekonomi, \& Akuntansi), 3(2), 184-190.

Arifudin, O. (2020). Analisis Budaya Organisasi Dan Komitmen Organisasi Karyawan Bank Swasta Nasional Di Kota Bandung. Jurnal Ilmiah MEA (Manajemen, Ekonomi, Dan Akuntansi), 4(Manajemen, Ekonomi, dan Akuntansi)), 73-87.

Fahmi. (2016). Manajemen Sumber Daya Manusia Teori dan Aplikasi. Bandung: Alfabeta

Handoko, H. (2014). Manajemen Personalia Dan Sumber Daya Manusia. Yogyakarta :BPFE.

Hasibuan. (2016). Manajemen Sumber Daya Manusia. Edisi Revisi. Jakarta: Penerbit PT Bumi Aksara.

Jackson, M. dan J. H. (2010). Human Resource Management.13th Edition. SouthWestern: Joseph Sabatino.

Mangkunegara, P. A. (2014). Manajemen Sumber Daya Manusia Dan Perusahaan. Jakarta : Rosda.

Rokhmawati, P. (2013). Analisis Penilaian Prestasi Kerja Pegawai. Jurnal Dinamika Manajemen, Vol 4 No 1, 23-29.

Simamora, H. (2014). Manajemen Sumber Daya Manusia. Yogyakarta : BPFE. 